\title{
Married Women's Employment in Rapidly Industrializing Societies: Examples from East Asia
}

\section{Citation}

Brinton, Mary C., Yean-Ju Lee, and William L. Parish. 1995. Married women's employment in rapidly industrializing societies: Examples from East Asia. American Journal of Sociology 100 , no. 5: 1099-1130.

\section{Published Version}

http://dx.doi.org/10.1086/230633

\section{Permanent link}

http://nrs.harvard.edu/urn-3:HUL.InstRepos:3219879

\section{Terms of Use}

This article was downloaded from Harvard University's DASH repository, and is made available under the terms and conditions applicable to Other Posted Material, as set forth at http:// nrs.harvard.edu/urn-3:HUL.InstRepos:dash.current.terms-of-use\#LAA

\section{Share Your Story}

The Harvard community has made this article openly available.

Please share how this access benefits you. Submit a story.

\section{Accessibility}




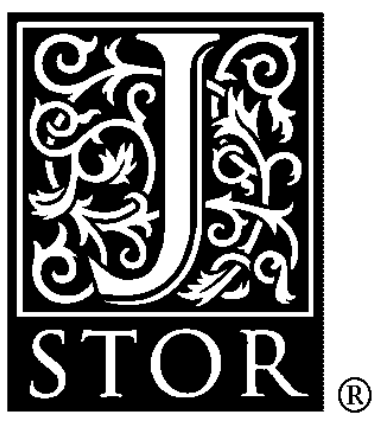

Married Women's Employment in Rapidly Industrializing Societies: Examples from East Asia Author(s): Mary C. Brinton, Yean-Ju Lee, William L. Parish

Source: The American Journal of Sociology, Vol. 100, No. 5, (Mar., 1995), pp. 1099-1130

Published by: The University of Chicago Press

Stable URL: http://www.jstor.org/stable/2782272

Accessed: 09/04/2008 11:29

Your use of the JSTOR archive indicates your acceptance of JSTOR's Terms and Conditions of Use, available at http://www.jstor.org/page/info/about/policies/terms.jsp. JSTOR's Terms and Conditions of Use provides, in part, that unless you have obtained prior permission, you may not download an entire issue of a journal or multiple copies of articles, and you may use content in the JSTOR archive only for your personal, non-commercial use.

Please contact the publisher regarding any further use of this work. Publisher contact information may be obtained at http://www.jstor.org/action/showPublisher?publisherCode=ucpress.

Each copy of any part of a JSTOR transmission must contain the same copyright notice that appears on the screen or printed page of such transmission.

JSTOR is a not-for-profit organization founded in 1995 to build trusted digital archives for scholarship. We enable the scholarly community to preserve their work and the materials they rely upon, and to build a common research platform that promotes the discovery and use of these resources. For more information about JSTOR, please contact support@jstor.org. 


\title{
Married Women's Employment in Rapidly Industrializing Societies: Examples from East Asia ${ }^{1}$
}

\author{
Mary C. Brinton \\ University of Chicago \\ Yean-Ju Lee \\ East-West Center \\ William L. Parish \\ University of Chicago
}

\begin{abstract}
A variety of explanations have addressed the phenomenon of secular change in married women's employment in rapidly industrializing countries. These include theoretical frameworks that emphasize female labor supply, the conditions of labor demand, patriarchal values, the international division of labor, and the effects of exportled industrialization. This article examines two societies (South Korea and Taiwan) that showed considerable similarity in female labor supply conditions, female labor force participation, and cultural values 20 years ago but have since diverged in dramatic and puzzling ways. Using aggregate and microlevel data, this article shows that the emergent differences in married women's employment are best explained by the intersection of labor supply (similar in the two cases) and demand (markedly different). The article highlights the impact of government policy and foreign loan investment in shaping the nature of labor demand during rapid export-led industrialization in both countries.
\end{abstract}

\section{INTRODUCTION}

The long-term secular increase in married women's economic participation in the 20th century across a range of countries has been a central

${ }^{1}$ Support from the Spencer Foundation, the National Institute of Child Health and Human Development (grant R01 HD23322), and the Chiang Ching Kuo Foundation is gratefully acknowledged. We also thank the Korean Women's Development Institute for allowing us to use the Korean data. Charles Chi-hsiang Chang provided research assistance for the paper. We received helpful comments from participants of the Labor Workshop and the Demography Workshop at the University of Chicago and from several AJS reviewers. Address all correspondence to Mary C. Brinton, Department of Sociology, 1126 E. 59th Street, University of Chicago, Chicago, Illinois 60637 .

(C) 1995 by The University of Chicago. All rights reserved.

0002-9602/95/10005-0001\$01.50 
focus of much recent research in sociology and economics (Goldin 1990; Mincer 1962; Shimada and Higuchi 1985; Smith and Ward 1985). This article critically evaluates several explanations of the sources of change in married women's economic participation. We take advantage of a semicontrolled "natural experiment" provided by two societies-South Korea and Taiwan - that began the push for industrialization roughly two decades ago with many similar initial conditions. Despite their similarities, these societies subsequently diverged in their incorporation of women into the economy. By the 1980s, married women in the two societies showed surprising differences in their age patterns of employment, types of employment, returns to education, and rates of pay compared to those of men. ${ }^{2}$

The combination of similar initial conditions with differing outcomes in a pair of societies provides a unique opportunity to examine the roles played by the interaction of labor supply, labor demand, patriarchal values, the international division of labor, and export-led economic industrialization in structuring married women's changing labor force participation. This article focuses on developing an explanation that takes into account the interaction of social and economic forces at both the domestic and international levels. This is especially important for an understanding of the economic role of women in societies in Asia, Latin America, and Eastern Europe that have recently industrialized in the context of an increasingly internationalized world economy. We begin by discussing existing modes of explanation, then evaluate them using macro- and microlevel data on South Korea and Taiwan.

\section{POSSIBLE EXPLANATORY MODELS}

The labor supply conditions that lead to increased female labor force participation have been well theorized: as age at marriage increases and fertility falls with industrialization, decreasing family obligations free more of women's time for labor market activities. Increases in human capital (both education and work experience) also generally make women more attractive employees and raise their potential wage rate, which pulls more women into the labor market (Goldin 1990). This type of explanation leads to the hypothesis that differences in the quantity and quality (i.e., wages and working conditions) of women's employment in Taiwan and South Korea hinge primarily on characteristics of women's labor supply: education, prior work experience, and fertility levels.

\footnotetext{
${ }^{2}$ For examples of the earlier literature on the patterns in each society, see Kim (1990), Cho and Koo (1983), KWDI (1986), Chang (1982), Liu (1984), Chiang and Ku (1985), ROC (1991b), Galenson (1992), and Kang (1993).
} 
Labor demand explanations suggest, however, that whether labor supply conditions such as increasing education and decreasing family obligations are translated into labor force participation depends on the nature of local labor markets (see, e.g., Chant 1991). In developing countries with low labor demand, women with more education may disdain the few lower paying, less prestigious jobs that are offered, leading to either an inverse or U-shaped relationship between women's education and work (Standing 1981; Smock 1981). Or, if demand for white-collar jobs remains modest, employers may reserve these jobs for men in order that they may earn a family wage. For example, in the United States and Britain before World War II and in Ireland until recently, strong "marriage bars" excluded educated married women from many white-collar jobs (Oppenheimer 1970; Goldthorpe 1987; Goldin 1990; Mincer 1962; Smith and Ward 1984; Pyle 1990).

A promising way of integrating supply-based and demand-based explanations is to analyze the nature of labor queues and women's place within them (Reskin and Roos 1990; Thurow 1969); that is, we may theorize that only when labor demand exceeds the supply of males in the queue will old prejudicial barriers to married women's employment fall. This type of explanation would lead to the hypothesis that differences between South Korea and Taiwan depend primarily on the level of labor demand in each society.

Explanations of married women's labor force participation that give primacy to patriarchal values suggest that, regardless of women's qualifications or the nature of labor demand, a myriad of cultural practices channel women into behaviors that either discourage labor force participation or encourage participation in only those jobs with the lowest income and prestige rewards (see, e.g., Papanek 1990). East Asian cultures such as Taiwan and South Korea are generally considered to be prime candidates for these types of explanations because of their strong extended-family, patrilineal descent traditions (see, e.g., Greenhalgh 1985; Salaff 1981; Jones 1984). Patriarchal values can affect behavior not only on the supply side but on the demand side as well, with policymakers, employers, and fellow employees making investment, hiring, training, and mentoring decisions that favor males over females (see, e.g., Pyle 1990). The hypothesis that emerges from this type of explanation is that differences between Taiwan and South Korea may be traced mainly to stronger patriarchal values in one of the two.

New international division of labor explanations typically argue that women at the periphery of the world economic system get the worst jobs in that system (see reviews in Pyle [1990], Tinker [1990], Wolf [1990], and Beneria and Feldman [1992]). One formulation of this idea places the blame for a large informal sector of makeshift, self-employed, service 
jobs on multinational corporations that make inappropriately capitalintensive investments in developing countries (e.g., Frobel, Heinrichs, and Kreye 1980; Evans and Timberlake 1980; Kentor 1981; Timberlake 1985; London 1987). Another formulation emphasizes how menial, laborintensive jobs are increasingly shifted from the core to the periphery of the world system, leading to a "fool's gold" explosion of jobs reserved only for young, single women who are dismissed as soon as they get married and begin having children (e.g., Nash and Fernandez-Kelly 1983; Sassen 1988). Either framework leads to the hypothesis that societies that are highly involved in the world economy produce inadequate demand for good jobs and this leads to employers' preference for young, unmarried women who will work for a few years at low wages and produce competitively priced goods for the world economy.

Finally, export-led growth explanations are popular in economic and World Bank circles. These offer the more optimistic view that suggests that unless local governments distort domestic factor markets (labor, capital, etc.), export production for the world market promotes laborintensive jobs that soak up so much underemployed labor that employers must eventually raise wages and hire married as well as unmarried women (see, e.g., Fields 1985; Galenson 1992; Krueger 1983; Lim 1990). Only countries that put barriers on imports and exports, who hem in labor with inappropriate legislation, or who mistakenly subsidize capital fail to enjoy these benefits. This type of explanation suggests the hypothesis that economies that have higher levels of export involvement and little government distortion of domestic factor markets will generate more and higher-quality opportunities for married female workers.

\section{METHODOLOGICAL APPROACH}

We assess the applicability of these competing frameworks with both macro- and microlevel data on Taiwan and Korea. Our macrolevel analysis attempts to explain society-level differences in urban married women's employment. The microlevel analysis attempts to explain specifically which married women get better-quality employment. We therefore combine a discussion of the intersocietal differences in women's employment that need to be explained with a discussion of how the theoretical frameworks outlined above either facilitate or hinder understanding.

We use macrolevel data from commonly available surveys in the two societies and microlevel data from specialized surveys on married women's work. The macrolevel data, mainly from annual government surveys, provide the context for understanding patterns in the microlevel data. The microlevel data are from two nationally representative surveys: the Taiwan Women and Family Survey carried out in 1989 in 


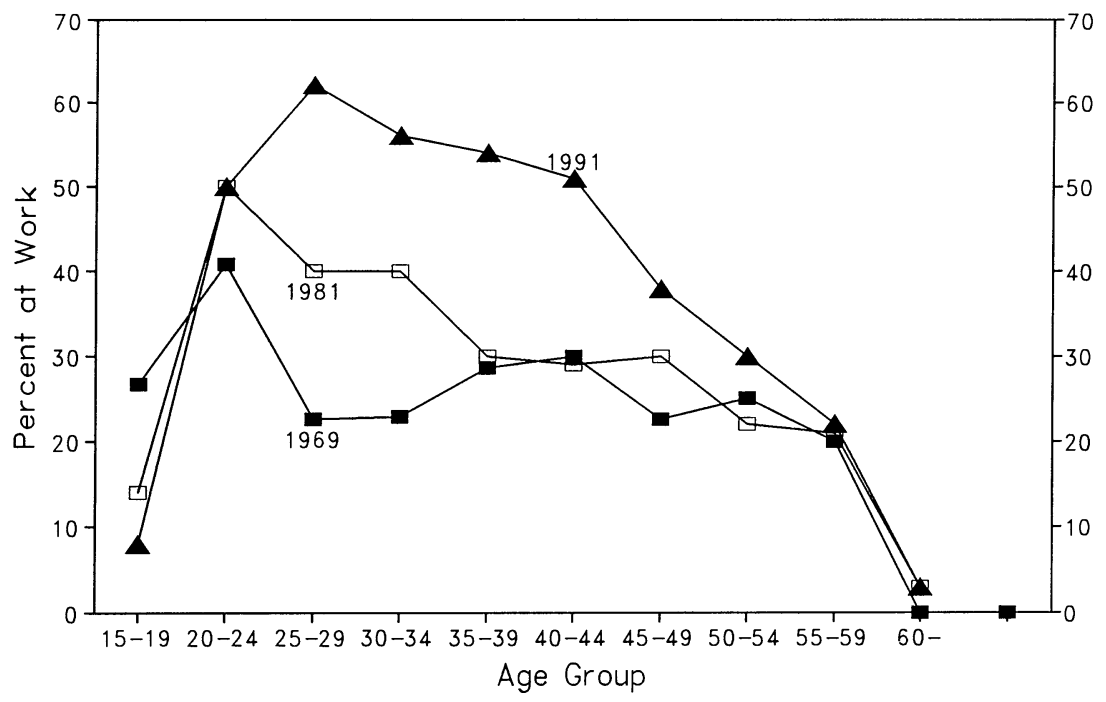

FIG. 1.-Women at work, Taipei City (ROC 1970, 1980, 1989)

Taiwan and the Survey of Women's Employment carried out in 1985 in South Korea. The Taiwan sample includes ever-married and nevermarried women 25-59 years old, while the Korean data are for ever-married women 15-59 years old. From each sample we select currently married women ages $25-49$ who live in urban areas. ${ }^{3}$ The emphasis on young and middle-aged married women in urban areas allows us to provide a fine-grained account of the opportunities and difficulties women face in the evolving labor market.

\section{WHAT NEEDS TO BE EXPLAINED}

Taiwan and South Korea have shared many conditions in common, including extremely rapid export-led growth that has placed them among the leading "miracle" economies of East Asia. Given many similarities in their economic growth patterns and world system positions, the existence of three major differences in women's labor force participation are puzzling. First, during the early years of export-led industrialization, female labor force participation was very similar in South Korea and Taiwan (figs. 1 and 2, bottom line). In 1970, when one-third to one-half

${ }^{3}$ To correct for a slight underrepresentation of large cities, the Taiwan data were weighted to accurately reflect the distribution of the urban population across different city sizes. 


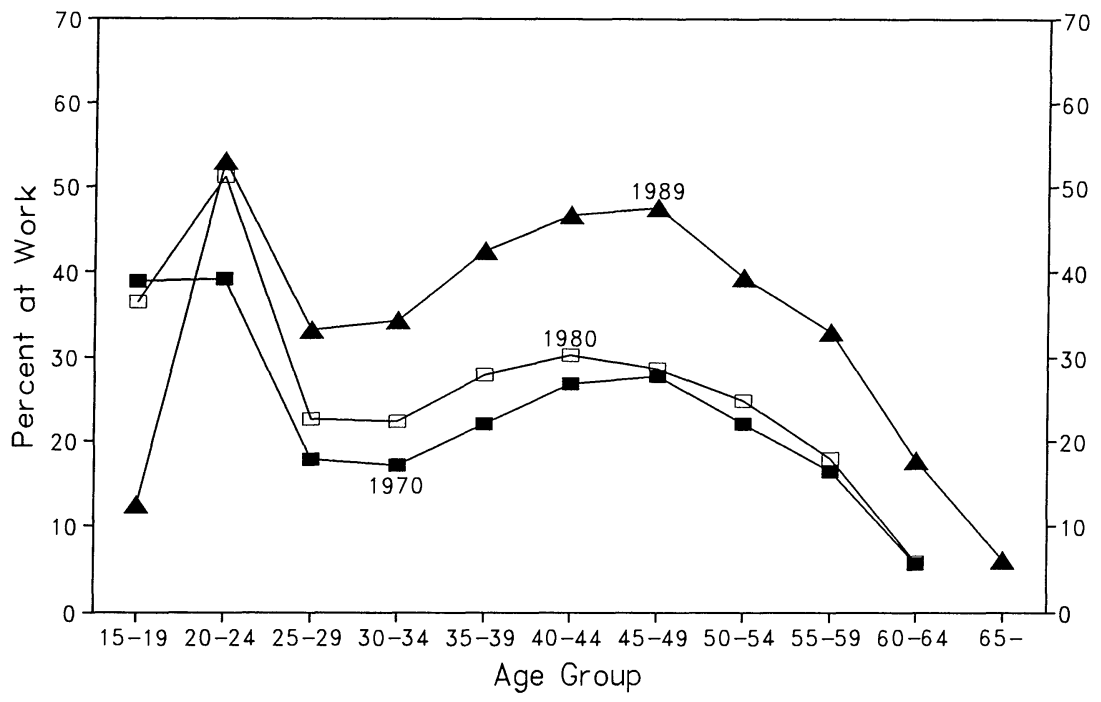

FIG. 2.-Women at work, urban Korea (ROK 1969, 1981, 1991a)

of the labor force remained in agriculture, women in both societies exhibited a pattern of delaying marriage while they worked. This was typically followed by a postmarital exit from the labor force. Despite these initial similarities in women's labor market behavior, the Korean and Taiwan patterns have since diverged (figs. 1 and 2, top lines). Older Korean women have increasingly entered the labor force once their children start school, a behavior that parallels and even exceeds similar patterns in Taiwan. But in great contrast to Taiwan, many Korean women in the prime childrearing ages of 25-34 years remain outside the labor force (see also Cho and Koo 1983).

Second, there are differences not only in the quantity of work for young married women but also in the quality of work available to all married women. Our microlevel data reinforce the macrolevel data in showing that the age-specific rates of labor force participation for married women are much lower in South Korea than in Taiwan (table 1). Korean married women ages 25-29 participate in the labor force at only one-half the rate of their Taiwan counterparts (27.1\% compared to $54.9 \%)$, and women's labor force participation rates remain lower in Korea than in Taiwan for older age groups as well. Note that this is mainly a result of the fact that Korean married working women are much less likely to be in formal employment (i.e., working as employees) than are women in Taiwan. Why do married women's rates of formal employment at any age in Taiwan so exceed their rates in South Korea? This is a puzzle. 
TABLE 1

Employment Status Distribution among Urban Married Women by Age

\begin{tabular}{|c|c|c|c|c|c|c|c|c|}
\hline \multirow[b]{2}{*}{$\begin{array}{l}\text { AGE GROUP } \\
\text { (in years) }\end{array}$} & \multicolumn{4}{|c|}{ TAIWAN } & \multicolumn{4}{|c|}{ SOUTH KoREA } \\
\hline & Employee & $\begin{array}{c}\text { Self- } \\
\text { Employed/ } \\
\text { Employer }\end{array}$ & $\begin{array}{c}\text { Family } \\
\text { Enterprise } \\
\text { Worker }\end{array}$ & $\begin{array}{l}\text { Total } \\
\text { FLFP }\end{array}$ & Employee & $\begin{array}{c}\text { Self- } \\
\text { Employed/ } \\
\text { Employer* }\end{array}$ & $\begin{array}{c}\text { Family } \\
\text { Enterprise } \\
\text { Worker }\end{array}$ & $\begin{array}{l}\text { Total } \\
\text { FLFP }\end{array}$ \\
\hline $25-29 \ldots \ldots \ldots$ & . $\quad 36.7$ & 13.0 & 5.3 & 54.9 & 8.1 & 12.5 & 6.5 & 27.1 \\
\hline $30-39 \quad \ldots \ldots \ldots \ldots$ & . $\quad 29.6$ & 18.3 & 10.1 & 58.0 & 13.8 & 17.0 & 8.1 & 38.9 \\
\hline $40-49 \quad \ldots \ldots \ldots .$. & . 30.0 & 19.8 & 7.8 & 57.6 & 19.8 & 15.8 & 11.6 & 47.2 \\
\hline All ages $\ldots \ldots$. & . 30.6 & 18.1 & 8.8 & 57.5 & 13.3 & 15.4 & 8.6 & 37.3 \\
\hline
\end{tabular}

SourCEs.-Taiwan Women and Family Survey (1989); Survey of Women's Employment (1985).

* Among Korean women who reported themselves as employees, those who work at their own house (i.e., domestic out-workers) are reclassified as self-employed.

Third, although we save detailed statistics until later, it is striking that the consequences of education differ in the two societies. In Taiwan, higher levels of female education lead uniformly to a higher probability of employment. In South Korea, just the opposite occurs. Among Korean married women, more education leads to a lower probability of employment, thereby violating standard models that predict that higher human capital leads to the promise of higher income, which in turn attracts women into the labor force.

These, then, are the three major differences that emerged for married women in the two societies by the mid-1980s: lower overall labor force participation in South Korea (most strikingly for young married women); lower rates of formal employment (employees working for wages or salaries) in South Korea; and the failure of higher human capital to lead to higher probabilities of employment in South Korea. Macrolevel data provide initial clues as to the applicability of the competing explanatory models outlined at the beginning of the paper.

\section{MACROLEVEL ANALYSIS}

\section{Labor Supply Conditions}

Taiwan and South Korea have shared many similar labor supply conditions (table 2). In 1970, mean age at first marriage was slightly lower in Taiwan, but the gap between the two societies narrowed and then disappeared entirely by the end of the 1980s. Likewise, the crude birth rate plummeted in both societies. A parallel rise in marriage age provided more opportunities for women to accumulate work experience before marriage in both countries, and a shortened childbearing period made it 
TABLE 2

LABOR SUPPLY CONDITIONS

\begin{tabular}{|c|c|c|c|c|c|}
\hline & 1970 & 1975 & 1980 & 1985 & 1990 \\
\hline \multicolumn{6}{|l|}{ Family obligations: } \\
\hline \multicolumn{6}{|l|}{ Age at first marriage, female: } \\
\hline 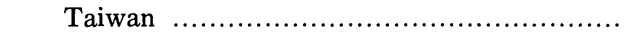 & 22.2 & 22.3 & 23.4 & 24.4 & 25.6 \\
\hline Korea $\ldots \ldots \ldots \ldots \ldots \ldots \ldots \ldots$ & 23.3 & 23.6 & 24.1 & 24.8 & 25.5 \\
\hline \multicolumn{6}{|l|}{ Crude birthrate: } \\
\hline Taiwan & 27.2 & 23.0 & 23.4 & 18.0 & 16.6 \\
\hline Korea ...... & 29.5 & 24.6 & 23.4 & 16.4 & 15.6 \\
\hline \multicolumn{6}{|l|}{ Education: } \\
\hline \multicolumn{6}{|l|}{$\begin{array}{l}\text { 12-17-year-olds in secondary education }(\%) \text { : } \\
\text { Taiwan: }\end{array}$} \\
\hline 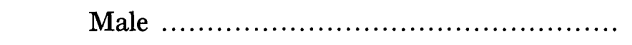 & NA & 69.5 & 71.9 & 77.9 & 83.6 \\
\hline 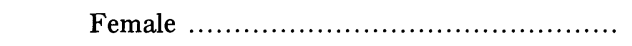 & NA & 61.7 & 70.0 & 78.6 & 87.4 \\
\hline \multicolumn{6}{|l|}{ Korea: } \\
\hline Male & 51.4 & 65.9 & 86.1 & 91.0 & 94.3. \\
\hline 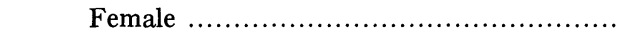 & 33.1 & 48.5 & 76.1 & 87.0 & 90.5 \\
\hline \multicolumn{6}{|l|}{ 18-21-year-olds in higher education (\%): } \\
\hline 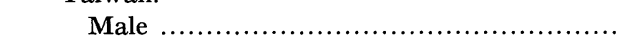 & NA & 11.2 & 11.9 & 14.2 & 18.3 \\
\hline Female ....... & NA & 8.7 & 10.2 & 13.5 & 19.6 \\
\hline \multicolumn{6}{|l|}{ Korea: } \\
\hline Male ........ & 13.9 & 13.9 & 25.2 & 51.0 & 50.8 \\
\hline 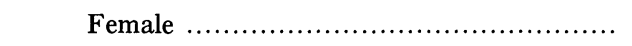 & 4.7 & 5.6 & 8.7 & 23.2 & 24.4 \\
\hline
\end{tabular}

SouRCES.-Taiwan: ROC (1991b, 1991c); Korea: KSA (1991b); ROK (1990, 1991).

NotE.-NA signifies that statistics were not available for this year.

possible for women to return to work sooner. Rising educational attainments also provided the conditions for an increase in women's labor force participation in both societies. Levels of female education have been slightly different; a higher proportion of women in Taiwan than in South Korea enrolled in secondary education, but Korean university enrollments overtook those in Taiwan. (Men's education patterns in Taiwan and Korea diverged, an important point to which we return later.) Examining female life-cycle patterns alone, the common phenomena of increasing age at marriage, declining child care obligations, and increasing education would lead labor supply explanations to predict not diverging but converging labor patterns for married women in the two societies. Thus, attention to labor supply conditions is clearly insufficient to explain the societal differences in women's labor force outcomes.

\section{Patriarchal Values}

Similarities in patriarchal values in the two societies also render incomplete a value-based explanation. Both societies share a common Confu- 
cian cultural tradition that emphasizes patrilineal and patrilocal family patterns. Until recently, it was common for women in Taiwan and South Korea to delay marriage while contributing some of their income to their family of birth and then to exit the labor market at least temporarily to concentrate on childrearing and household chores (Greenhalgh 1985; Jones 1984). Though there of course may be some distinctions between Taiwan and South Korea in sex-role values, the two societies have been quite similar (see, e.g., Arnold and Kuo 1984; Lee 1985). Without the benefit of detailed evidence on systematic, subtle differences between the countries from the initial time point of our analysis (1970) to the late 1980 s, it is difficult to see how such differences could have led to the dramatic divergence in married women's work patterns. In light of the cultural commonalities, an explanation giving primacy to patriarchal values would predict similar, not divergent, female labor force patterns. Indeed, the initial similarity in work patterns around 1970 suggests that shared cultural values once did lead to similar outcomes. In these earlier years, analysts of Taiwan noted that premarital work for one's parental family was followed by a postmarital retreat from the labor force (see Greenhalgh 1985; Jones 1984; Salaff 1981). Moreover, employers were eager to hire single women but reluctant to employ women after marriage (Diamond 1979; Kung 1983), illustrating the type of "marriage bar" phenomenon that existed at an earlier time in the United States, Britain, and Ireland (Goldin 1990; Pyle 1990). These patriarchal patterns, however, appear to have had much less impact on later Taiwan work patterns, which suggests that we must move beyond this level of explanation to account for differences between South Korea and Taiwan in the 1980s.

\section{Labor Demand Conditions}

Both societies have been highly involved in the world market. As measured by export volume, however, Taiwan (with exports equal to $60 \%$ of GDP in 1986) has been more highly involved than South Korea (whose exports equal 35\% of GDP; see Ranis 1992, p. 257; IBRD 1988, p. 243). Though neither society has had very much direct foreign investment of the sort that might skew capital intensity in production, South Korea has received massive foreign loans through subsidized government channels in ways that could skew production and labor markets. ${ }^{4}$ These differences between the two societies have affected aggregate labor demand, educated labor demand, and job flexibility.

${ }^{4}$ To the extent that either society had direct foreign investment, some scholars conclude that the employment effects were either neutral or positive (Koo 1985; Ranis and Chi 1985; Tu 1990). 
Aggregate labor demand.-One of the factors emphasized in export-led growth explanations is how government intervention in capital markets can distort the types of industries that are promoted. There are two principal ways that this could have an impact on the labor market for married women: (1) the relative emphasis on heavy versus light industry and (2) the emphasis on more capital intensive production, which leads to lower aggregate labor demand. We examine first the issue of industrial structure and its relationship to women's labor force participation (excluding agriculture) using 1989 labor force surveys for each country. Contrary to expectations, it is not the case that Taiwan's industrial distribution is more dominated than Korea's by light manufacturing or other industries that traditionally employ large numbers of women (see col. 1, appendix table A1). The industrial distributions of the two countries are in fact very similar, with some light industries such as food manufacturing, textiles, insurance, and real estate composing slightly more of the total nonagricultural labor force in Korea than in Taiwan. It is also striking that the proportion female in each industry is with few exceptions higher in Taiwan; across virtually all industrial categories, there are simply fewer women employed in Korea than in Taiwan.

While it appears unlikely that industrial structure per se is related to the lower employment rates of Korean women, it is much more probable that government policies encouraging capital intensity have had a significant effect through lowered labor demand and the concentration of "acceptable" white-collar jobs in large firms (we discuss the latter under Job flexibility, below). In the 1970s, South Korean production became more capital intensive while Taiwan production moved in the opposite direction. In South Korea a great influx of foreign capital has been funneled through government-subsidized loans to massive urban-centered business conglomerates (chaebol) that became more capital intensive (Amsden 1989; Hong 1979, 1983; Kim 1989; Mason et al. 1980). In contrast, Taiwan experienced little foreign borrowing and few government loans, and initial industrialization involved a myriad of small enterprises scattered throughout small towns and cities (e.g., Amsden 1991; Hamilton and Biggart 1988). By many accounts, the low levels of capital infusion and the highly labor-intensive methods in these small firms exhausted Taiwan's labor surplus as early as 1968 (Blank and Parish 1990; Galenson 1979; Lundberg 1979; Ranis 1992). Thus, the Korean government's preferential policies toward chaebol led to greater capital intensity while government policies in Taiwan led in the other direction, toward labor intensity. In short, the observed differences between the two societies are consistent with an export-led growth explanation that emphasizes the capital intensity of firms.

Changes in urban unemployment patterns over time are also consistent 
with this mode of explanation. In Korea, urban unemployment continued to be a nagging problem for years (see table 3; see also Fields 1985; Galenson 1992). The large numbers of migrants who left the industryimpoverished countryside could not all find jobs in capital-intensive industry. In Taiwan, in contrast, urban unemployment remained at extremely low levels, and by the early to mid-1980s employers increasingly complained about labor shortages and the need to hire illegal foreign laborers (e.g., Speare, Liu, and Tsay 1988; Chang 1987). Similar trends in South Korea did emerge but not until the late 1980s, when unemployment began to be replaced by labor shortages, especially in small and medium-sized firms. This delayed labor shortage coincided with the belated rise in older Korean women's labor force participation in the late 1980s (see fig. 2). These parallels among the capital intensity of investment, the urban concentration of investment, urban unemployment rates, and married women's employment are consistent with the exportled explanation.

Educated labor demand. - Unemployment of the well-educated is common throughout much of the developing world, and explanations of the phenomenon typically emphasize features such as "the diploma disease," whereby educational credentials become the primary means to enter a modern sector that has dramatically higher incomes than the traditional sector (e.g., Dore 1976). The returns to education in South Korea as contrasted with Taiwan demonstrate the rampant credentialism in Korea. Heretofore, there has been a greater education premium in South Korea than in Taiwan (table 3). ${ }^{5}$

Regardless of its causes-be they the greater capital intensity of large firms or Korean employers' strong preference to hire the best graduates from the best schools - this pattern of educational returns has given parents and children a strong incentive to pressure the government to relax controls over secondary school and college enrollments. Consistent with this pressure, Korean male secondary school and university admissions grew dramatically in the late 1970s and early 1980s (see table 2 above). With the subsequent explosion in the number of secondary school and university graduates entering the labor market, it is perhaps not surprising that by the early 1980s unemployment among the educated was much greater in Korea than in Taiwan, where secondary school and university admissions remained more tightly controlled (table 3). As Michell suggests, "The Republic of Korea has a classic case of the diploma disease. . . . The imperfections of the labor market also mean that many well-educated people do not get jobs commensurate with their educa-

${ }^{5}$ As Amsden (1989) notes, the pattern of high returns to education in the midst of high unemployment among the educated is very curious and is difficult to explain. 
TABLE 3

Labor Market Conditions in TaIwan and South Korea

\begin{tabular}{|c|c|c|c|c|c|}
\hline & 1970 & 1975 & 1980 & 1985 & 1990 \\
\hline \multicolumn{6}{|l|}{ Unemployment rates $(\%)$ : } \\
\hline \multicolumn{6}{|l|}{ National: } \\
\hline Taiwan .. & 2.1 & 2.1 & 1.2 & 3.2 & 1.4 \\
\hline 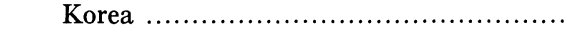 & 4.4 & 4.1 & 5.2 & 4.0 & 2.4 \\
\hline \multicolumn{6}{|l|}{ Urban: } \\
\hline Taiwan (Taipei City) & NA & NA & 1.7 & 3.6 & 1.8 \\
\hline Korea $($ Nonfarm) .......... & 7.4 & 6.6 & 7.5 & 4.9 & 2.9 \\
\hline \multicolumn{6}{|l|}{ Unemployment by education: } \\
\hline \multicolumn{6}{|l|}{ Taiwan: } \\
\hline 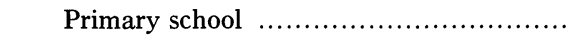 & 1.4 & 1.4 & .5 & 1.5 & 1.3 \\
\hline Middle school ............................... & 2.6 & 3.6 & 1.4 & 3.2 & 1.7 \\
\hline Secondary school $\ldots$. & 3.9 & 5.8 & 2.7 & 4.8 & 2.5 \\
\hline College ................ & 3.3 & 4.3 & 2.3 & 4.2 & 2.2 \\
\hline \multicolumn{6}{|l|}{ Korea: } \\
\hline Primary school & NA & NA & 2.7 & 1.5 & 0.7 \\
\hline Middle school & NA & NA & 6.3 & 4.1 & 1.8 \\
\hline Secondary school & NA & NA & 9.3 & 5.9 & 3.4 \\
\hline College ............ & NA & NA & 6.2 & 6.6 & 4.5 \\
\hline \multicolumn{6}{|l|}{ Paid-employee female/male income ratios: } \\
\hline 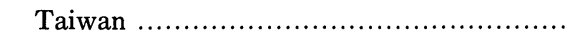 & NA & .51 & .65 & .65 & .65 \\
\hline 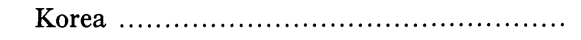 & NA & .42 & .43 & .47 & .53 \\
\hline \multicolumn{6}{|l|}{ Paid-employee returns to education: } \\
\hline \multicolumn{6}{|l|}{ Secondary/primary ratios: } \\
\hline 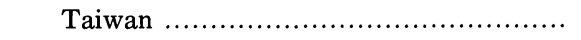 & NA & 1.47 & 1.23 & 1.19 & 1.12 \\
\hline Korea ….................................. & NA & 1.75 & 1.45 & 1.34 & 1.19 \\
\hline \multicolumn{6}{|l|}{ University/primary ratios: } \\
\hline Taiwan .................... & NA & 2.36 & 1.94 & 2.14 & 1.79 \\
\hline 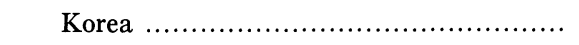 & NA & 3.75 & 3.32 & 3.03 & 2.21 \\
\hline \multicolumn{6}{|l|}{ Employees in large firms:* } \\
\hline \multicolumn{6}{|l|}{ Taiwan: } \\
\hline $500+$ employees & NA & NA & 8.6 & 7.4 & 7.7 \\
\hline $100+$ employees $\ldots$. & NA & NA & 26.9 & 26.5 & 23.9 \\
\hline \multicolumn{6}{|l|}{ Korea: } \\
\hline 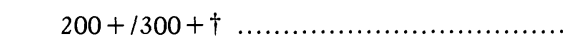 & 52.1 & 51.9 & 42.4 & 36.3 & 34.6 \\
\hline
\end{tabular}

SourCES.-Taiwan: ROC (1987, 1990, 1991a, 1991b, 1991c); Korea: ROK (1991) and KSA (1991a, $1991 b)$.

Note. - NA signifies that statistics were not available for this year.

* This excludes government employment and includes in the denominator only firms with 10 or more employees.

$\dagger$ This is $200+$ employees through 1975 , and $300+$ employees starting in 1980. 
tion" (1988, pp. 104-6). Korea produced too many college graduates in the 1980s for a society with only modest labor demand in the nonmanual sector (see Amsden 1989; Mason et al. 1980; McGinn et al. 1980). Moreover, when surveyed in 1984, Korean enterprises replied that their labor shortages were not in managerial, clerical, or sales jobs but in skilled manual (40\%), unskilled manual (17\%), and engineering jobs (14\%-18\%) (Amsden 1989, p. 225). In short, the queue of job applicants was likely to be the longest for educated applicants, with much of this applicant queue being composed of highly educated males.

From these observations on total labor demand and the long queues of highly educated males in South Korea, the low levels of Korean married women's paid employment begin to make sense. Much as in the United States or Britain before World War II, an adequate supply of educated males for clerical and other skilled jobs has provided little incentive for Korean employers to lower bars to married women's employment. This is in great contrast to Taiwan, where an inadequate supply of educated males has forced employers to alter their patriarchal preferences. As an example, commercial banks in Taiwan abolished the marriage bar in the late 1970s, and by the late 1980s private firms generally no longer asked women to quit upon marriage. In contrast, employer pressure on women to resign from white-collar jobs at the time of marriage has been very strong in Korea and has begun to diminish only in the late 1980s. With the passage of an Equal Opportunity Law in 1987, employer pressure on women to resign has become more indirect than previously (Korea Association of Women Friends 1989).

Job flexibility. - A final aspect of labor demand concerns the types of jobs common in the two societies. In South Korea, one of the consequences of government-subsidized loans to large urban businesses is that nonagricultural jobs are likely to be located in large firms in large cities, a situation that requires a lengthy journey to work and long, inflexible work hours (e.g., Amsden 1991; Deyo 1989; Hamilton and Biggart 1988; Koo 1985). In the 1970s, when many of the work habits of today were being established, over half of all Korean private-sector enterprises with 10 or more workers had more than 200 workers (see table 3). Even by 1990 , if we define a "large" firm as one with 300 or more workers, over one-third of Korean private sector employees have continued to be in large enterprises. In contrast, less than $10 \%$ of Taiwan employees in private firms with 10 or more workers are in large firms of 500 or more. Even when one uses the very lax standard of 100 or more workers, only one-fourth of Taiwan firms are large. Thus, on average, the Taiwan employee works in enterprises of a more modest scale, where connections between employer and employee are likely to be more informal and arrangements for working mothers are probably easier to work out. 
Commuting times have also remained longer in Korea. In 1990, the average Korean worker commuted 31 minutes to work, while even in Taiwan's largest city of Taipei, the average worker commuted only 24 minutes to work. In all large cities in Taiwan a worker averaged only 18 minutes, and in smaller cities he or she averaged only 13 minutes in commuting to work each day. Thus, for women, the tension between work and family appears to have been greater in Korea than in Taiwan. These facts fit both the export-led growth explanation, which emphasizes distortions due to government policy, and the labor supply explanation, which emphasizes the potential role of family responsibilities in keeping women out of the labor force.

In summary, the facts suggest that it is not just supply-side conditions or foreign-loans/government intervention that are important. Rather, it is the intersection of supply conditions (which are similar between the two societies) and the demand conditions created by government policy and the nature of foreign loan investment (dissimilar between the two societies). The development of capital-intensive production in South Korea kept aggregate labor demand lower than in Taiwan, while at the same time Korea's countryside was emptying migrants into the country's largest cities. The excess of educated workers was exacerbated by government policies that allowed the number of places at Korean universities to expand in response to the growing demand for education. Finally, foreign loans to the Korean government were allocated principally to chaebol, thus fueling the growth of large firms. Long commutes and long working hours have been the result. In all of these ways, the nature of labor demand has been shaped in such a way that the opportunities for married women - particularly the highly educated - to work in the formal sector have been hindered in South Korea to a degree that contrasts with the situation in Taiwan. We explore this in more detail with microlevel survey data.

\section{MICROLEVEL ANALYSIS}

If our macrolevel analysis is correct, the effects of women's supply-side characteristics should differ sharply in Taiwan and South Korea because these factors interact with very different demand-side conditions in the two societies. We first show how premarital work experience differently shapes postmarital work for women in Taiwan and South Korea; then we examine the different effects of supply-side factors on married women's current employment.

Work before and after Marriage

Examining young women's work before and after marriage shows how human capital accumulated through prior work experience promotes 
TABLE 4

EMPloyment STATUS AND OCCUPATIONAL Distribution BEFORE AND AFTER MARRIAGE AMONG URBAN MARRIED WOMEN AgES 25-29*

\begin{tabular}{|c|c|c|c|c|c|c|c|c|}
\hline & \multicolumn{4}{|c|}{ TAIWAN } & \multicolumn{4}{|c|}{ SOUTH KOREA } \\
\hline & \multicolumn{2}{|c|}{ Before } & \multicolumn{2}{|c|}{ After } & \multicolumn{2}{|c|}{ Before } & \multicolumn{2}{|c|}{ After } \\
\hline & (\%) & $(N)$ & (\%) & $(N)$ & (\%) & $(N)$ & (\%) & $(N)$ \\
\hline Self-employed & 2.0 & 4 & 23.6 & 27 & 4.0 & 16 & 45.8 & 63 \\
\hline Family-enterprise worker & 5.0 & 9 & 9.7 & 11 & 7.1 & 28 & 24.2 & 33 \\
\hline Employees & 93.0 & 181 & 66.7 & 76 & 88.9 & 358 & 30.0 & 41 \\
\hline Administrative/managerial ..... & .0 & 0 & .9 & 1 & .0 & 0 & .0 & 0 \\
\hline Professional/technical ........... & 8.9 & 17 & 10.3 & 12 & 11.3 & 45 & 12.5 & 17 \\
\hline 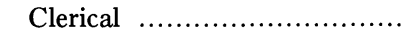 & 32.0 & 62 & 31.1 & 35 & 37.3 & 151 & 1.4 & 2 \\
\hline Sales $\ldots \ldots \ldots \ldots \ldots \ldots \ldots \ldots \ldots \ldots$ & 3.9 & 8 & 3.7 & 4 & 3.4 & 14 & .7 & 1 \\
\hline 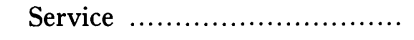 & 10.2 & 20 & 8.4 & 10 & 2.0 & 8 & 4.6 & 6 \\
\hline ................. & 38.0 & 74 & 12.4 & 14 & 34.4 & 138 & 10.1 & 14 \\
\hline 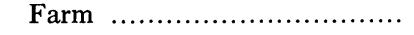 & .0 & $\underline{0}$ & .0 & $\underline{0}$ & .5 & 2 & .7 & 1 \\
\hline Total in labor force ............ & $\overline{100.0}$ & $\overline{194}$ & $\overline{100.0}$ & 113 & $\overline{100.0}$ & $\overline{402}$ & $\overline{100.0}$ & $\overline{137}$ \\
\hline Not in labor force $\ldots \ldots \ldots \ldots \ldots \ldots$ & 5.8 & 12 & 45.1 & 93 & 20.6 & 104 & 72.9 & 369 \\
\hline$N \quad \ldots \ldots \ldots \ldots \ldots \ldots \ldots \ldots \ldots$ & & 206 & & 206 & & 506 & & 506 \\
\hline
\end{tabular}

SourCES.-Taiwan Women and Family Survey (1989); Survey of Women's Employment (1985).

* Educational levels of the two samples are standardized using the Taiwanese distribution as the reference.

work in paid (formal) employment in one society but not in the other. The sharp discontinuity between pre- and postmarital work gives further proof of the persistence of a marriage bar in South Korea (table 4). ${ }^{6}$ The proportion of working women who are employees before marriage is very similar in the two societies (93\% in Taiwan and $89 \%$ in South Korea). After marriage, the proportion of working married women who are employees drops to $67 \%$ in Taiwan; this contrasts with a more precipitous drop in South Korea to $30 \%$. Conversely, the proportion of Korean working women in family enterprises and especially in self-employment rises sharply after marriage.

Turning to the occupational distribution among the formally employed, about one-third of single female workers in each society are clerical employees, another one-third are manufacturing employees, and the remainder are distributed throughout the major occupational categories. A higher proportion of single female workers in Taiwan are employees in service jobs, but other than that there are few premarital differences.

\footnotetext{
${ }^{6}$ In order to eliminate differences between the two countries' occupational distributions that might be produced by educational differences in the samples of women, we standardized Korea's educational distribution against Taiwan's for the purpose of table 4 .
} 
The occupational distribution of married women, however, is radically different in the two societies. In Taiwan, the proportion of all married women workers employed in clerical jobs is virtually the same as that for single women workers. But in South Korea, this figure drops from $37 \%$ before marriage to $1 \%$ after marriage. In short, it is extremely rare for young married female workers in South Korea to be in clerical jobs, whereas about one-third of this population of women in Taiwan are in clerical work. In contrast, the proportion of working women who are professional or technical employees remains about the same in the preand postmarital populations of Korea; this mainly represents women in the teaching profession, one of the few white-collar occupations open to married women.

One might ask whether married women eventually return to whitecollar work. To investigate this, we also examined the premarital and current occupational distribution for women 45-49 years old (not shown). For this cohort also, the proportion of women workers in clerical jobs before marriage is similar in the two societies (around 20\%). But about $14 \%$ of working women in Taiwan occupy such positions in their late forties, compared to $2 \%$ of women in South Korea. Thus our conclusions are not restricted only to young married women; older married women in South Korea also show an extremely low propensity to be involved in lower-level white-collar work. The proportions of older women in administrative/managerial work either before or after marriage are trivial in both societies, as is the case for the younger cohort as well. These comparisons further strengthen the conclusion that, for married women, the differences between the two societies in the quality of employment (specifically, access to white-collar jobs in the formal sector) are as great or greater than the differences in the propensity to be employed.

\section{Current Work}

Analysis of whether married women currently work and, if so, in what types of jobs also demonstrates a very strong interaction between the characteristics a woman supplies to the labor market and the environment she encounters there.

Methods.-As independent variables, we emphasize the qualities a woman supplies to the labor market. The first group of qualities makes up her human capital. As already suggested, we infer that educational attainment will be positively related to women's formal employment in Taiwan but not in South Korea because of the greater competition from educated males and a continuing marriage bar in clerical jobs. We also include work experience in the equation and expect a similar result. Educational attainment is measured by four categories: primary school 
or less, middle school, secondary school, or college or more. ${ }^{7}$ Work experience is measured as whether the woman worked before marriage.

The second group of variables includes husband's income, measured as monthly earnings, and his employment status, which is categorized as employee, self-employed or employer, and not working. ${ }^{8}$ We control for employment status because it is expected to have an important effect on the wife's type of labor force participation (e.g., wives of self-employed men are more likely to be family-enterprise workers). Our analytical focus is on the effect of husband's income net of this variable, with our expectation being that when labor market opportunities are constrained by a marriage bar the alternative of depending on husband's income will be more common.

The third group of variables represents household structure and family life-cycle characteristics (extended family structure, age of youngest child, number of children, and woman's age). With the exception of age of youngest child, these are included as control variables in the analysis. Household structure is considered extended if respondents lived with their parent(s) or parent(s)-in-law; it is considered nuclear otherwise. Age of youngest child is categorized into three groups: birth to two years, three to five years, and six years old or older. Woman's age is categorized as 25-29 years, 30-39 years, and 40-49 years. Distributions of the independent variables for both samples are shown in table $5 .^{9}$

For the analysis of the determinants of married women's formal employment, we use a multinomial logit model that contrasts nonwork with formal employment, self-employed work, and family-enterprise work. We keep these three categories of work separate because of the major differences in the content and rewards of self-employment, familyenterprise work, and formal employment and because much of the implicit emphasis in our analytical models is on societal differences in formal employment. For each society we present two sets of models: a short model that includes women's human capital acquired before marriage

\footnotetext{
${ }^{7}$ While it would be desirable to retain junior colleges and universities as distinct categories, the number of women with university education is too low to permit this.

${ }^{8}$ We do this for two reasons: (1) classifying self-employed or family-enterprise workers by occupation is probably not conceptually meaningful and (2) our interest in the occupational distribution lies in the prediction of a flow of married women out of white-collar occupations. This is predicated on the idea of a marriage bar resulting from the actions of employers, and thus these actions are only relevant in cases where women are employees.

${ }^{9}$ For various reasons, married women ages 25-29 are underrepresented in the Taiwan sample. But because these are the women most likely to be in paid employment (see table 1 above), age biases in the sample serve not to overstate but instead to understate the differences we ascribe to Taiwan and South Korea. Moreover, aggregate statistics from government labor force surveys parallel the patterns we report here.
} 
TABLE 5

Characteristics OF URban Married Women

\begin{tabular}{|c|c|c|}
\hline & Taiwan & South Korea \\
\hline \multicolumn{3}{|l|}{ Level of education:* } \\
\hline Primary school or less & 38.1 & 31.0 \\
\hline 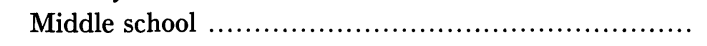 & 16.0 & 28.5 \\
\hline 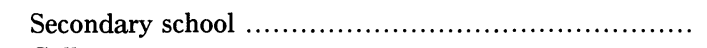 & 30.4 & 33.3 \\
\hline College or more $\ldots \ldots \ldots \ldots \ldots \ldots \ldots \ldots \ldots \ldots \ldots$ & 15.5 & 7.2 \\
\hline \multicolumn{3}{|l|}{ Work before marriage: } \\
\hline 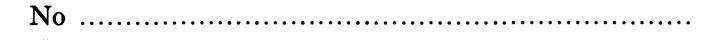 & 11.7 & 32.7 \\
\hline 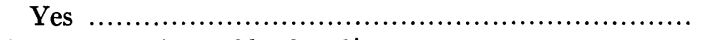 & 88.3 & 67.3 \\
\hline Average earnings of husband $\dagger$ & 25,871 & 403,360 \\
\hline U.S. dollar values .............. & 743.85 & 482.70 \\
\hline \multicolumn{3}{|l|}{ Husband's employment status: } \\
\hline Employee .................. & 65.8 & 64.1 \\
\hline Employer/self-employed & 31.1 & 26.5 \\
\hline Not working $\ldots \ldots \ldots \ldots \ldots$ & 3.1 & 9.4 \\
\hline \multicolumn{3}{|l|}{ Family type: } \\
\hline 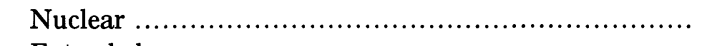 & 84.9 & 88.3 \\
\hline 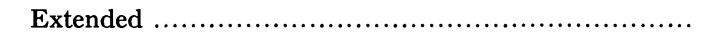 & 15.1 & 11.7 \\
\hline \multicolumn{3}{|l|}{ Age of youngest child: } \\
\hline $0-2$ years old $\ldots \ldots \ldots$ & 16.9 & 24.7 \\
\hline 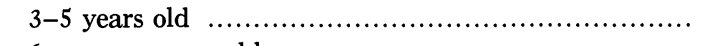 & 19.9 & 24.5 \\
\hline 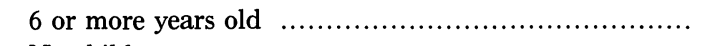 & 59.8 & 46.2 \\
\hline No children & 3.4 & 4.6 \\
\hline \multicolumn{3}{|l|}{ Age: } \\
\hline $25-29$ years old & 12.3 & 29.7 \\
\hline 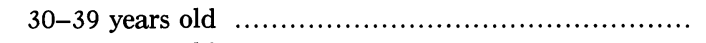 & 56.0 & 45.3 \\
\hline 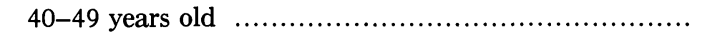 & 31.7 & 25.0 \\
\hline
\end{tabular}

SourCES.-Taiwan Women and Family Survey (1989); Survey of Women's Employment (1985).

* Values other than averages are percentages.

$\dagger$ Units are Taiwanese yuan and Korean won. U.S. dollar values are used for the analysis.

(education and work experience), husband's employment status, and family life-cycle characteristics, and a long model that adds husband's income.

Results. - The multinomial logit results for current types of work further demonstrate how women's employment in the two societies is shaped by conditions in the labor market (tables 6 and 7). As anticipated, education and premarital work experience affect married women's formal employment differently in the two societies. In the short model for Taiwan, education has a positive linear effect on a woman's probability of being an employee, with college education having a particularly strong effect. Experience in the labor market before marriage is also positively related to formal employment. The positive linear effect of education does not 
hold for a woman's self-employment or for employment as a familyenterprise worker. Instead, these employment statuses are generally more likely to be occupied by the less educated.

In the short model for South Korea (table 7), education is negatively related to formal employment, although this effect is not linear: secondary school graduates are the least likely to work as employees, and the effect of college education is negative but not statistically significant. Work before marriage is not significantly related to formal employment after marriage. The general negative relationship between education and employment persists for self-employment and family-enterprise work as well, and work experience bears no relationship to these forms of employment. In both societies, wives whose husbands are employers or selfemployed workers are less likely than other women to be employees and are much more likely to work in family enterprises (probably owned by their husbands). ${ }^{10}$

In addition to the direct effects of education, we anticipated that the link between Korean wives' education and formal employment would be mediated through their husband's income to a greater extent than in Taiwan. As shown in the long model for Taiwan (table 6), the coefficients for the effects of wife's education on formal employment remain quite stable when husband's income is included in the equation. Husband's income itself is negatively related to the probability of the wife working as an employee. In South Korea (table 7), the magnitude of the negative effect of husband's income on wife's formal employment is larger than in Taiwan. Moreover, controlling for husband's income has an impact on the influence of wife's education. Middle school education no longer has a significant dampening effect on wife's formal employment, the magnitude of the high school effect is reduced, and the effect of college education is positive rather than negative (although still statistically insignificant). This offers support for our assumption that a married woman's education has an indirect effect on her employment via husband's income in South Korea but not in Taiwan. In Korea an educated woman facing

${ }^{10}$ In models combining all three types of employment (not shown here), education has little effect on women's overall employment in Taiwan because of its offsetting effects on different types of employment. Only college education has a significant positive relationship with women's employment. In Korea, on the other hand, education has consistently negative effects on all three types of employment and thus shows a very strong negative relationship with aggregate employment. For both countries, the effect of the husband being an employer or a self-employed worker is also strongly related in a positive direction to the wife's working. This is because the positive effect on the wife's probability of being a family-enterprise worker (as well as self-employed in the case of Taiwan) overrides the negative effect on her probability of being an employee. These patterns hold in both the short and long models. 


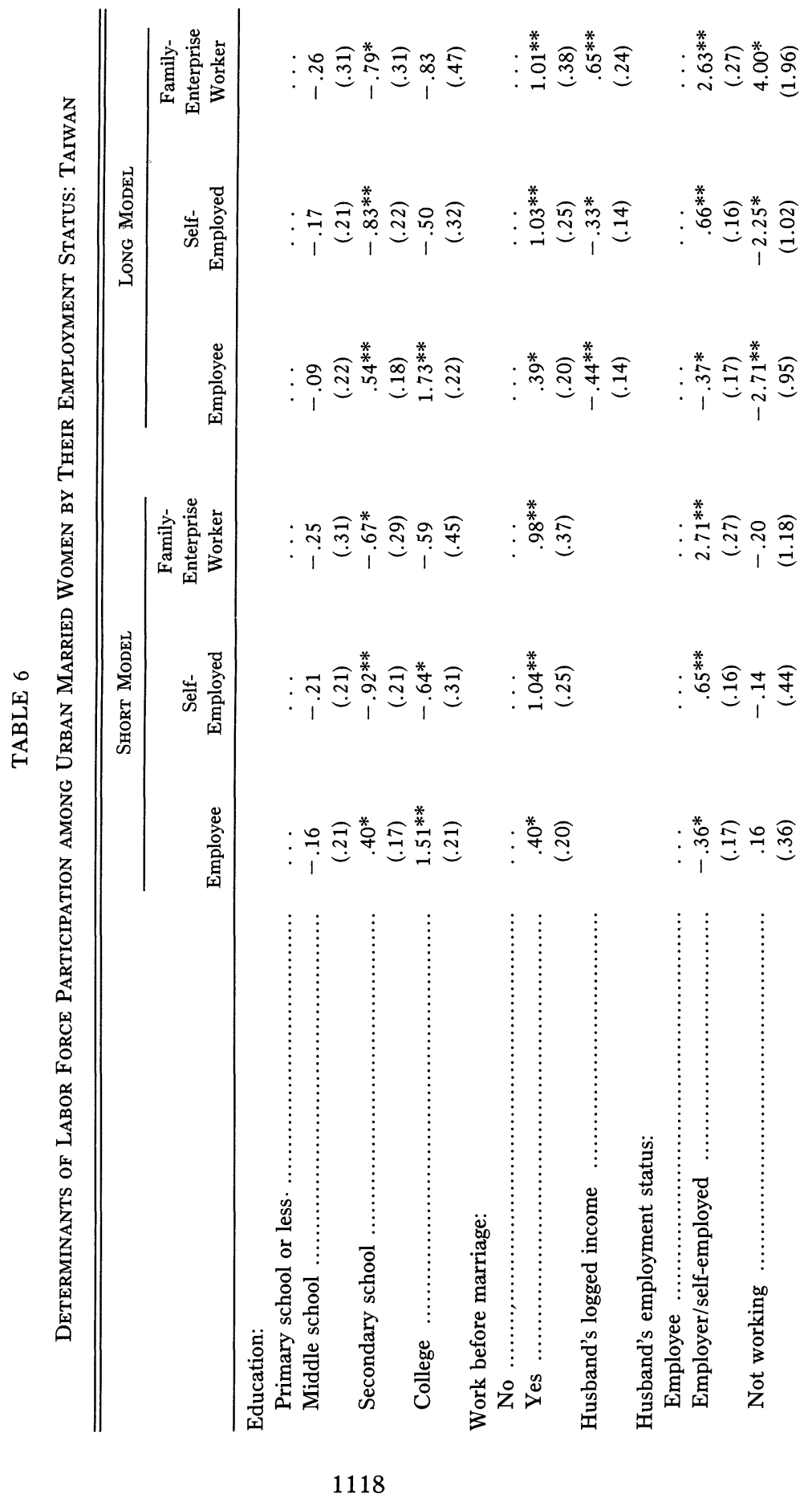




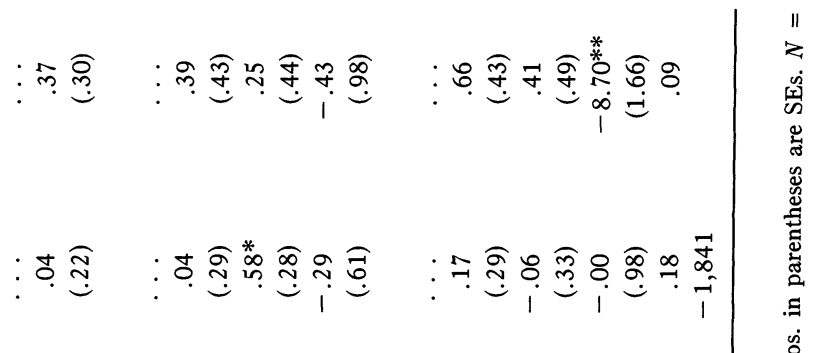

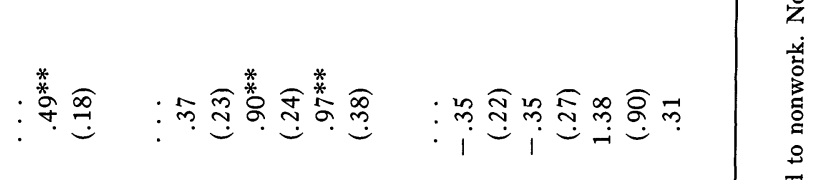

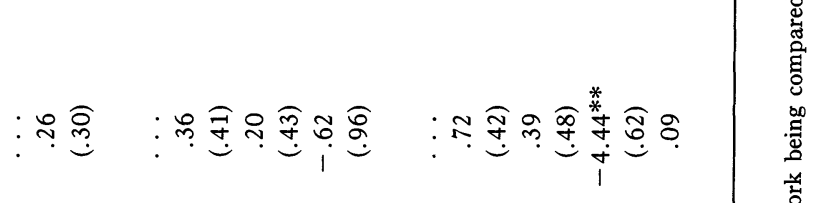

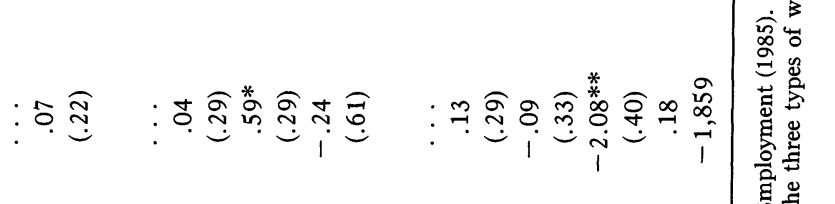

$$
\begin{aligned}
& : \text { : }
\end{aligned}
$$

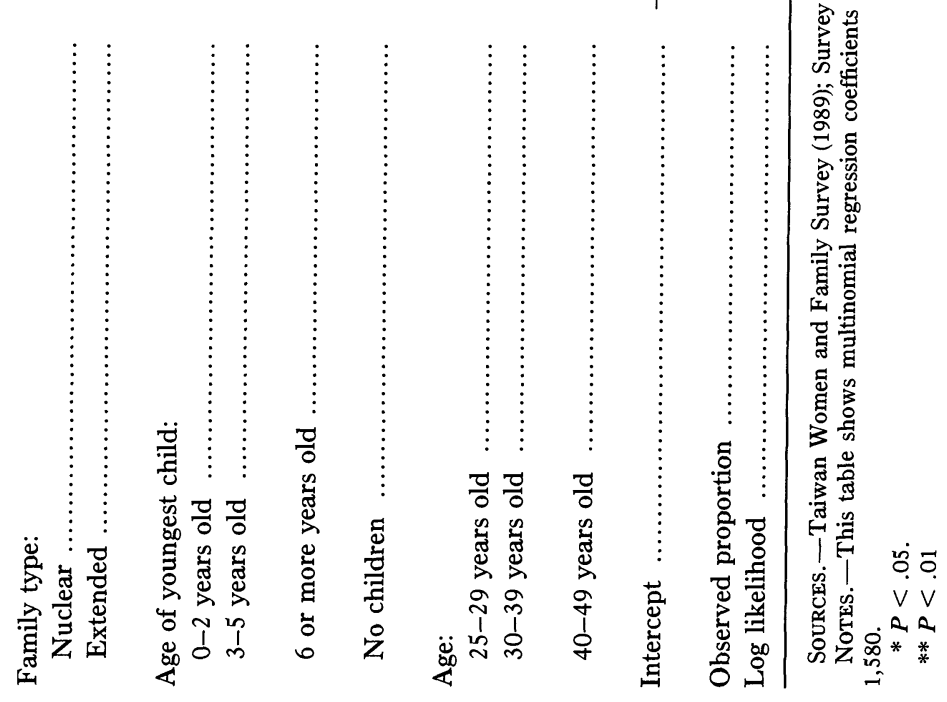




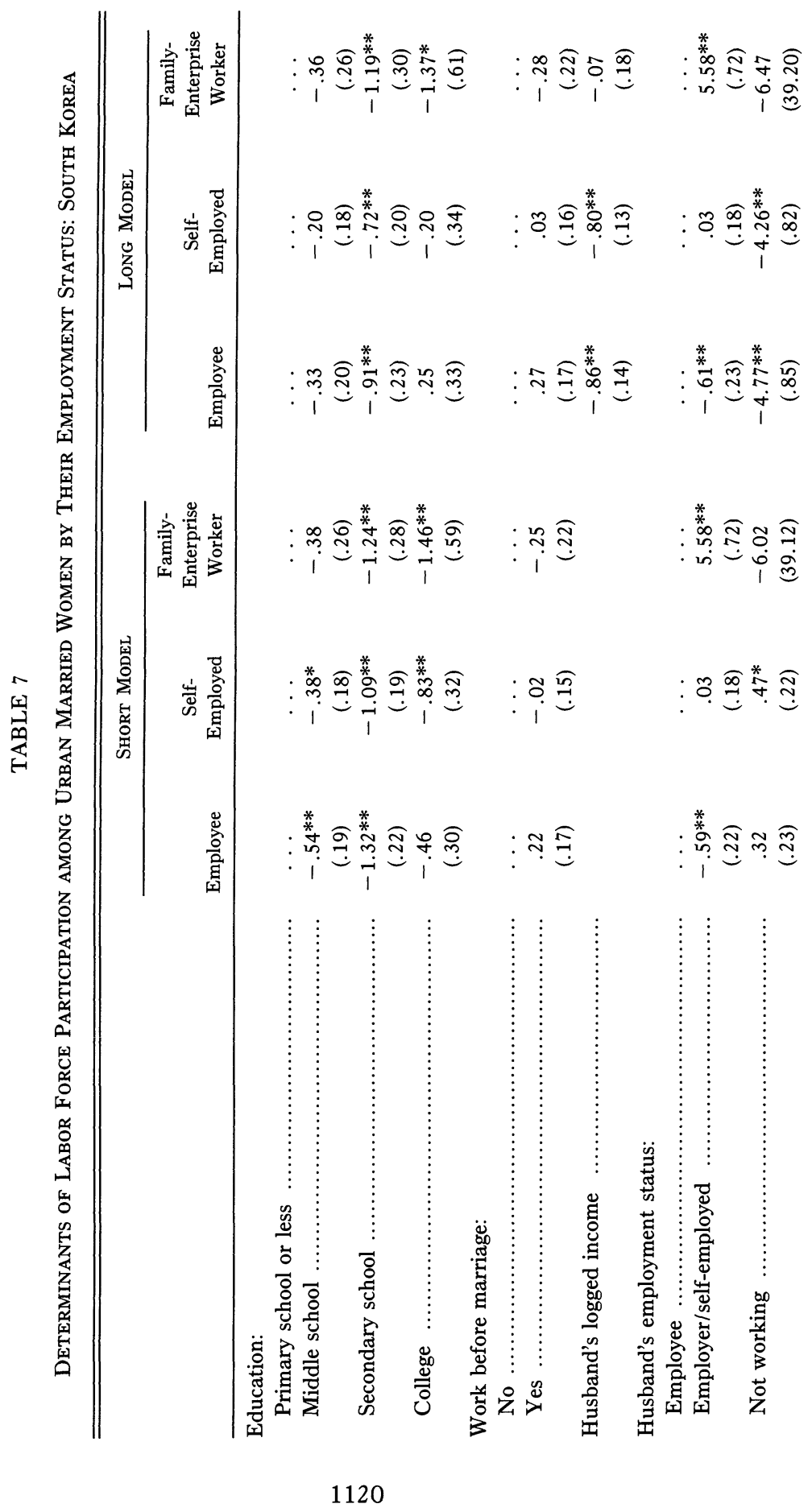




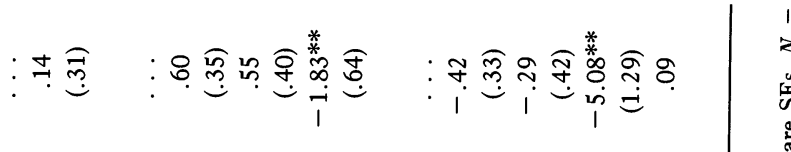

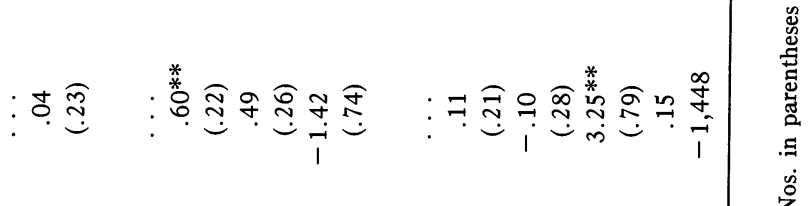

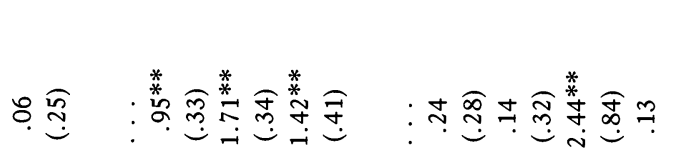

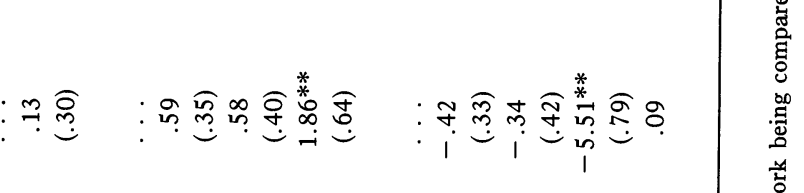

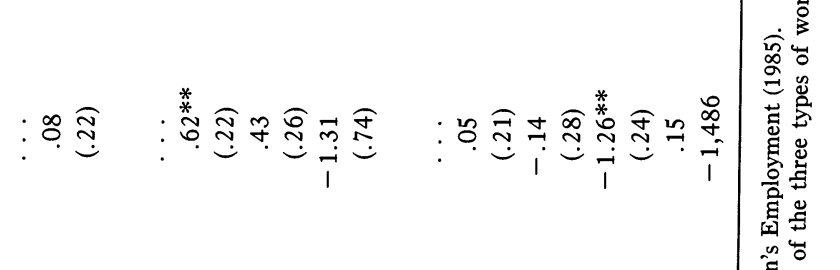

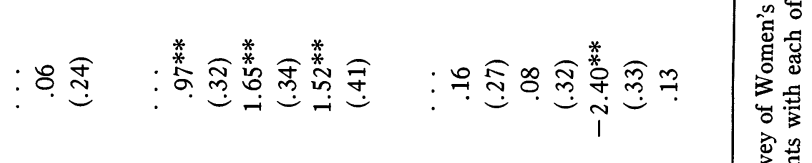

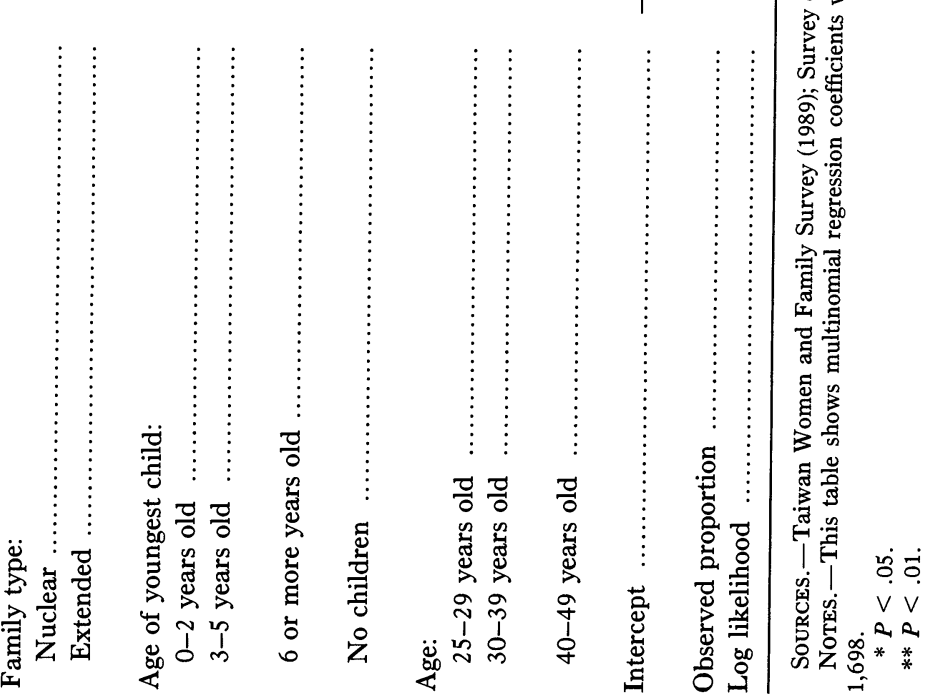


the marriage bar in employment is more likely to use her educational credentials to compete in the marriage market for a husband who will provide an adequate income. Success in this marriage market will free her from working in the lower-status, lower-income jobs open to her. ${ }^{11}$

Based on our observation of aggregate work patterns by age and on information on the lower quality of jobs that are open to married women, we expected that Korean women with preschool children would be less likely to work than their counterparts in Taiwan. As predicted, although formal employment is positively related to the age of the youngest child in both societies, Korean women with a child under two years old are particularly likely to be nonemployees. The effects of youngest child's age are stronger for women in Korea than in Taiwan. This completes our list of labor supply conditions whose effects are shaped by the differing labor demand situation in each country.

Two general questions remain. First, are the differences in the effects of independent variables for the two societies statistically significant? Second, to what extent can the intersociety differences in married women's formal employment be attributed to the two societies' different distributions on the independent variables that measure women's human capital, husbands' characteristics, and household characteristics? To answer the first question, we tested for interaction effects between each independent variable and a dummy variable for the society. The difference in the effects of secondary school and college education on married women's formal employment are statistically significant for Taiwan and South Korea, and this holds whether the effects are direct or indirect (mediated through husband's income). The effect of husband's income is also significantly stronger in South Korea than Taiwan. Thus our major generalizations receive strong support. The difference in the effects of work experience and youngest child's age for the two societies is substantial but not statistically significant.

To answer the question of whether differences in the characteristics of Taiwanese and Korean women have a strong impact on the intersociety differences in employment probabilities, we calculated the probability of each type of employment based on the logit results given in tables 6 and 7 (substituting the mean for each independent variable); we also calculated the probability of employment in each society using the variable

\footnotetext{
${ }^{11}$ Although not shown here, the relationship between wife's education and husband's logged income, controlling for wife's age, is positive and strong in both countries. But the regression coefficient for wife's education is larger in South Korea than it is in Taiwan. The relationship between husband's and wife's education is also stronger in South Korea-which fits the social science literature describing how educated Korean women divert their energies from the labor market to the marriage market (e.g., Kim 1990; Park 1991).
} 
TABLE 8

Estimated Probabilities of Employment among URban MARRIED WOMEN BY EMPLOYMENT STATUS

\begin{tabular}{|c|c|c|c|c|c|c|}
\hline & \multicolumn{3}{|c|}{ TAIWAN } & \multicolumn{3}{|c|}{ SOUTH KOREA } \\
\hline & Employee & $\begin{array}{c}\text { Self- } \\
\text { Employed }\end{array}$ & $\begin{array}{l}\text { Family- } \\
\text { Enterprise } \\
\text { Worker }\end{array}$ & Employee & $\begin{array}{c}\text { Self- } \\
\text { Employed }\end{array}$ & $\begin{array}{l}\text { Family- } \\
\text { Enterprise } \\
\text { Worker }\end{array}$ \\
\hline $\begin{array}{l}\text { Estimated directly from } \\
\text { logit results } \ldots \ldots \ldots \ldots \ldots\end{array}$ & .309 & .178 & .042 & .111 & .159 & .004 \\
\hline $\begin{array}{l}\text { Estimated assuming } \\
\text { sample composition of } \\
\text { the other country ..... }\end{array}$ & .311 & .154 & .023 & .110 & .128 & .007 \\
\hline
\end{tabular}

Sources. - Taiwan Women and Family Survey (1989); Survey of Women's Employment (1985).

means for the other society. Table 8 contains the results. The likelihood of Korean women working as paid employees is roughly one-third that for women in Taiwan, and these probabilities are barely altered when the sample composition of the other society is assumed. Also, consistent with the figures presented in table 5, the likelihood of self-employment and family-enterprise work is quite similar in the two societies. This is not strongly altered by standardizing each society for the sample characteristics of the other. Thus it is not the case that the differences we observe in urban married women's employment in Taiwan and South Korea are produced by differences in women's characteristics; rather, it is the way these characteristics are translated into employment that varies by society.

\section{DISCUSSION}

Our analyses demonstrate the insufficiency of labor supply explanations in explaining married women's employment. Women's education, premarital work experience, and fertility are very similar in the two societies we examined. So, in aggregate comparisons between South Korea and Taiwan, labor supply conditions are a constant that cannot explain the different outcomes in the two places. Moreover, microlevel analyses show that labor supply conditions (as in the case of education and premarital work experience) lead to opposite outcomes or different magnitudes of outcomes (the case of child care responsibilities and husband's income) in the two societies. These results can be understood only by paying attention to the intersection between supply and demand factors in each society. 
Much the same can be said for patriarchal-value-based explanations. In earlier periods, patriarchal-based explanations helped account for the very similar female labor market patterns in the two societies. Patriarchal culture supported a rigid marriage bar that kept young married women out of many jobs, particularly the better-paying, more secure jobs as paid employees. One can only understand why this marriage bar weakened in one society and remained strong in the other by paying attention to the intersection between cultural factors and demand factors. When total demand for labor remained relatively flaccid and the supply of educated males ample, employers found it easy to continue old cultural preferences for educated males. When demand for labor was strong and the supply of educated males inadequate, old cultural barriers fell. Thus, as in the United States and Britain after World War II, old cultural barriers to married women's work soon weakened. It is not that patriarchal-valuebased explanations are wrong; rather they are insufficient without attention to the labor demand environment in which values are enacted.

New international division of labor accounts are inadequate for two reasons. First, early versions tend to lead to a uniform set of predictions for societies at the periphery of the world system. A foreign-investmentbased prediction is not helpful, for direct foreign investment remained minimal in the two societies. When variation among societies is predicted by the new international division of labor, it is inconsistent with many of the observed patterns in Taiwan and South Korea. This view suggests that a society with greater world market involvement will have more labor market problems-a formal sector with menial or unskilled deadend jobs open only to single women and a large informal sector made up of self-employed and family-enterprise jobs-but this is inconsistent with the two cases we have examined. Taiwan's exports totaled a staggering $60 \%$ of GDP compared to a figure of $35 \%$ for South Korea. Yet barriers to married women in the formal sector and the existence of a large informal sector more accurately characterize Korea than Taiwan.

An export-led growth framework proves more productive for explaining the divergence in married women's labor force participation in our two cases. Export-led growth explanations suggest how government distortion of factor markets can weaken otherwise positive effects of export-led growth on women's employment. This is consistent with the labor-intensive, dispersed industrialization pattern of Taiwan versus the more capital-intensive, large urban conglomerate industrialization pattern of South Korea. The Korean government's decision to promote large, capital-intensive enterprises by privileging them with foreign loans does appear to have had important consequences. The prospect of long commuting times and rigid working hours in large enterprises has created difficulties for urban Korean married women to balance work and family 
responsibilities. Moreover, the government's promotion of large conglomerates in the 1970s raised wages for the more educated, which in turn caused parents to put more pressure on policymakers to relax secondary and higher education enrollment limits. This led to higher levels of educated unemployment and to longer job queues with males at the front and females at the rear. As a result, the fall of marriage bars to married females in white-collar jobs in the formal sector of the Korean economy has been considerably delayed in comparison to Taiwan.

We also draw two general conclusions from our analyses. First, we argue for the utility of reviving theoretical attention to the intersection of supply factors and demand factors in the labor market. Discussions of U.S. and British labor markets before World War II, the Irish labor market in the past few decades, and developing-country labor markets show that the analysis of married women's employment can be quite complex during periods of significant economic transition (Oppenheimer 1970; Standing 1981; Smock 1981; Goldin 1990; Mincer 1962; Smith and Ward 1984; Pyle 1990). Our results from Taiwan and South Korea demonstrate clearly that attention to the unique intersection of supply and demand is critical in understanding that complexity.

Our second general conclusion is related to the first. In order to understand properly the nature of labor demand in a country-a proximate determinant of women's labor force participation-it is important to pay attention to the ways that domestic government policy affects that demand. Accounts stemming from the "new international division of labor" tradition frequently fall short by predicting quite uniform consequences for societies at the periphery of the world market. Though export-led growth explanations are rather skeletal in providing only a checklist of market distortions to search for, they have the virtue of focusing attention on how the interaction between government policies and world market position shapes aggregate, urban, and educated labor demand. This is crucial for understanding the different labor market outcomes for married women in rapidly industrializing societies such as Taiwan and South Korea.

\section{APPENDIX}

\section{Industry-Specific Demand}

Appendix table A1 shows the surprising similarity in the industrial distribution of the labor force in Taiwan and South Korea. Moreover, there do not appear to be systematic industrial differences in the proportion of employed females in the two countries; in nearly all cases, there is a 


\section{TABLE A1}

Nonagricultural Industrial Distribution and Women's Employment Share In TaIwan ANd South Korea, 1989

\begin{tabular}{|c|c|c|c|c|c|c|}
\hline & \multicolumn{3}{|c|}{$\begin{array}{c}\text { INDUSTRIAL } \\
\text { DistRIBUTION (\%) }\end{array}$} & \multicolumn{3}{|c|}{ FEMAle Share (\%) } \\
\hline & Taiwan & Korea & $(\mathrm{T}-\mathrm{K})$ & Taiwan & Korea & $(\mathrm{T}-\mathrm{K})$ \\
\hline \multicolumn{7}{|l|}{ Primary Products: } \\
\hline Coal mining & .1 & .3 & -.2 & 11.1 & 5.4 & 5.7 \\
\hline Petroleum .......... & .1 & .0 & .1 & 20.0 & .0 & 20.0 \\
\hline Metal ore mining & .0 & .1 & -.1 & .0 & .0 & .0 \\
\hline Other mining ....... & .1 & .2 & -.0 & 10.0 & 10.0 & .0 \\
\hline \multicolumn{7}{|l|}{ Light manufacturing: } \\
\hline Food...$\ldots \ldots \ldots \ldots \ldots$ & 2.1 & 2.8 & -.7 & 35.8 & 41.2 & -5.4 \\
\hline Textile .............. & 7.3 & 9.2 & -1.9 & 65.5 & 51.3 & 14.1 \\
\hline 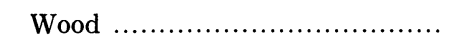 & 2.0 & 1.3 & .7 & 27.9 & 19.0 & 8.8 \\
\hline$\ldots \ldots \ldots \ldots \ldots \ldots \ldots \ldots \ldots \ldots \ldots \ldots \ldots \ldots$ & 1.9 & 1.8 & .1 & 31.1 & 25.6 & 5.6 \\
\hline Chemicals, petroleum products $\ldots$ & 5.6 & 2.6 & 3.1 & 41.1 & 26.6 & 14.5 \\
\hline Nonmetallic ........................ & 1.3 & 1.3 & .0 & 34.7 & 20.5 & 14.3 \\
\hline \multicolumn{7}{|l|}{ Heavy manufacturing: } \\
\hline Basic metal & .9 & .9 & .0 & 15.9 & 6.2 & 9.7 \\
\hline Fabricating metal, machinery ..... & 15.4 & 11.3 & 4.0 & 36.2 & 22.5 & 13.8 \\
\hline Other manufactures $\ldots \ldots \ldots \ldots \ldots \ldots$ & 2.5 & 2.2 & .3 & 53.1 & 45.8 & 7.3 \\
\hline \multicolumn{7}{|l|}{ Public utilities: } \\
\hline 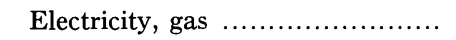 & .4 & .3 & .0 & 10.7 & 6.7 & 4.0 \\
\hline 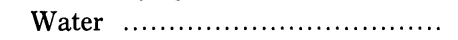 & .1 & .1 & .0 & 28.6 & 12.5 & 16.1 \\
\hline \multicolumn{7}{|l|}{ Construction: } \\
\hline Construct-general & 5.9 & 7.3 & -1.4 & 13.0 & 7.2 & 5.8 \\
\hline Construct-special $\ldots \ldots \ldots \ldots \ldots \ldots \ldots$ & 2.8 & 1.7 & 1.1 & 6.0 & 7.8 & -1.8 \\
\hline \multicolumn{7}{|l|}{ Commerce: } \\
\hline Wholesale ....... & 5.0 & 3.2 & 1.8 & 61.6 & 29.1 & 32.5 \\
\hline Retail ......... & 13.2 & 18.0 & -4.8 & 43.6 & 46.3 & -2.7 \\
\hline Restaurants $\ldots \ldots \ldots \ldots \ldots \ldots \ldots \ldots$ & 4.2 & 7.2 & -3.0 & 49.0 & 61.7 & -12.7 \\
\hline \multicolumn{7}{|l|}{ Transportation/business services: } \\
\hline Transport and storage $\ldots \ldots \ldots \ldots \ldots$ & 5.4 & 5.7 & -.3 & 13.4 & 5.9 & 7.4 \\
\hline Communication ........................ & .8 & .6 & .2 & 24.6 & 21.8 & 2.8 \\
\hline Financial institutions ................ & 1.7 & 1.8 & -.1 & 47.9 & 39.3 & 8.6 \\
\hline Insurance $\ldots \ldots \ldots \ldots \ldots \ldots \ldots \ldots \ldots$ & .7 & 1.0 & -.3 & 61.2 & 64.7 & -3.4 \\
\hline Real estate, business services ...... & 1.9 & 2.7 & -.8 & 42.9 & 21.3 & 21.6 \\
\hline \multicolumn{7}{|l|}{ Services: } \\
\hline Public administration $\ldots . . . . . . . . . .$. & 4.3 & 3.4 & .9 & 32.5 & 15.3 & 17.2 \\
\hline 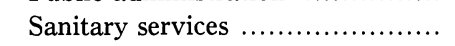 & .1 & .2 & -.1 & 40.0 & 19.2 & 20.8 \\
\hline Social services $\ldots \ldots \ldots \ldots \ldots \ldots \ldots \ldots$ & 7.7 & 6.8 & .9 & 54.3 & 43.6 & 10.7 \\
\hline Recreational services $\ldots \ldots \ldots \ldots \ldots . . . .$. & .8 & 1.2 & -.4 & 45.5 & 34.6 & 10.8 \\
\hline Personal services $\ldots . . . \ldots \ldots \ldots \ldots \ldots . . . . . . .$. & 5.7 & 4.8 & .9 & 48.9 & 54.7 & -5.8 \\
\hline International bodies & .0 & .1 & -.1 & .0 & 11.8 & -11.8 \\
\hline $\begin{array}{l}\text { Average . } \\
\text { Total .... }\end{array}$ & & & & 39.0 & 34.6 & 4.4 \\
\hline Total $\ldots$ & 100.0 & 100.0 & .0 & & & \\
\hline
\end{tabular}

SOURCES.-Taiwan: ROC (1989); Korea: ROK (1989).

NoTES.- "T - K" = Taiwan $\%$ minus Korean \% with a plus result meaning more in Taiwan and a minus result meaning more in Korea. "Female share" = female as a $\%$ of all employees in each industry. 
higher proportion female in Taiwan. ${ }^{12}$ When we standardize each country's industrial distribution to the other's, surprising results are produced (see Durand [1975] and Pyle [1990] for similar analyses for other countries). Korea's overall $34.6 \%$ female share declines to $32.2 \%$ after standardizing to Taiwan's industrial distribution, and Taiwan's $39.0 \%$ share increases to $40.7 \%$ when the industrial distribution is standardized to Korea's. This is the opposite of what would be expected if it were Korea's greater emphasis on heavy industry (or conversely, Taiwan's emphasis on light industry) that was producing country divergence in female employment. Only minor shifts occur when one standardizes on occupational rather than industrial categories, and the direction of change is once again in the opposite direction that one would predict. In short, across virtually all categories (other than a few limited categories such as restaurant and retail trade), be they heavy or light manufacturing, social services, or public administration, there are simply fewer women employed in Korea than there are in the comparable sector in Taiwan.

\section{REFERENCES}

Amsden, Alice H. 1989. Asia's Next Giant: South Korea and Late Industrialization. New York: Oxford University Press.

- 1991. "Big Business and Urban Congestion in Taiwan: The Origins of Small Enterprise and Regionally Decentralized Industry (Respectively)." World Development 19:1121-35.

Arnold, Fred, and Eddie C. Y. Kuo. 1984. "The Value of Daughters and Sons: A Comparative Study of the Gender Preferences of Parents." Journal of Comparative Family Studies 15:299-318.

Beneria, Lourdes, and Shelley Feldman, eds. 1992. Unequal Burden: Economic Crises, Persistent Poverty, and Women's Work. Boulder, Colo.: Westview.

Blank, Grant, and William Parish. 1990. "Rural Industry and Non-Farm Employment." In Chinese Urban Reform, edited by Reginald Kwok, William L. Parish, and Anthony Yeh. Armonk, N.Y.: M. E. Sharpe.

Brinton, Mary C. 1993. Women and the Economic Miracle: Gender and Work in Postwar Japan. Berkeley and Los Angeles: University of California Press.

Chang, Ching-hsi. 1982. "The Labor Force Participation of Married Women in Taiwan" (in Chinese). Pp. 97-127 in The Chinese Economic Association Annual Conference Proceedings. Taipei.

- 1987. "Foreign Workers: A Preliminary Economic Analysis" (in Chinese). Pp. 198-216 in The Fiftieth Symposium on Social Sciences. Taipei: Academia Sinica, Institute of the Three Principles of Peoples.

Chant, Sylvia. 1991. Women and Survival in Mexican Cities. Manchester: Manchester University Press.

Chiang, L. N., and Y. Ku. 1985. Past and Current Status of Women in Taiwan. Taipei: National Taiwan University, Population Studies Center.

Cho, Uhn, and Hagen Koo. 1983. "Economic Development and Women's Work in a Newly Industrializing Country: The Case of Korea." Development and Change 14:515-32.

12 The percentage differences in this comparison are muted because the comparison includes unmarried as well as married women and because it includes women of all ages. 
Deyo, Frederic C. 1989. Beneath the Miracle: Labor Subordination in the New Asian Industrialism. Berkeley and Los Angeles: University of California Press.

Diamond, Norma. 1979. "Women and Industry in Taiwan." Modern China 5: 317-40.

Dore, Ronald. 1976. The Diploma Disease. Berkeley: University of California Press.

Durand, John. 1975. The Labor Force in Economic Development: A Comparison of International Census Data, 1946-1966. Princeton, N.J.: Princeton University Press.

Evans, Peter, and Michael Timberlake. 1980. "Dependence, Inequality, and the Growth of the Tertiary." American Sociological Review 45:531-52.

Fields, Gary S. 1985. "Industrialization and Employment in Hong Kong, Korea, Singapore, and Taiwan." In Foreign Trade and Investment: Economic Development in the Newly Industrializing Asian Countries, edited by Walter Galenson. Madison: University of Wisconsin Press.

Frobel, Folker, Jurgen Heinrichs, and Otto Kreye. 1980. The New International Division of Labour: Structural Unemployment in Industrialised Countries and Industrialisation in Developing Countries. Cambridge: Cambridge University Press.

Galenson, Walter. 1979. "The Labor Force, Wages, and Living Standards." Pp. 384-447 in Economic Growth and Structural Change in Taiwan, edited by Walter Galenson. Ithaca, N.Y.: Cornell University Press.

- 1992. Labor and Economic Growth in Five Asian Countries: South Korea, Malaysia, Taiwan, Thailand and the Philippines. New York: Praeger.

Gereffi, Gary, and Donald L. Wyman, eds. 1990. Manufacturing Miracles: Paths of Industrialization in Latin America and East Asia. Princeton, N.J.: Princeton University Press.

Goldin, Claudia Dale. 1990. Understanding the Gender Gap. New York: Oxford University Press.

Greenhalgh, Susan. 1985. "Sexual Stratification: The Other Side of 'Growth with Equity' in East Asia." Population and Development Review 11:265-314.

Hamilton, Gary, and Nicole Woolsey Biggart. 1988. "Market, Culture, and Authority: A Comparative Analysis of Management and Organization in the Far East." American Journal of Sociology 94:S52-S94.

Hong, Won-tack. 1979. Trade, Distortions and Employment Growth in Korea. Seoul: Korea Development Institute.

- 1983. "Export Promotion and Employment Growth in South Korea." In Trade and Employment in Developing Countries, vol. 1. Edited by Anne O. Krueger. Chicago: University of Chicago Press.

IBRD (International Bank for Reconstruction and Development). 1988. World Development Report 1988. Washington, D.C.: Oxford University Press.

Jones, Gavin W. 1984. "Economic Growth and Changing Female Employment Structures in the Cities of Southeast and East Asia." Pp. 17-60 in Women in the Urban and Industrial Workforce: Southeast and East Asia, edited by Gavin W. Jones. Honolulu: University of Hawaii Press.

Kang, Seyoung. 1993. "Differences in the Process of Earnings Determination and Inequality between Women and Men in South Korea." Korea Journal of Population and Development 22:215-38.

Kentor, Jeffrey. 1981. "Structural Determinants of Peripheral Urbanization: The Effects of International Dependence." American Sociological Review 46:201-11.

Kim, Changsoo. 1989. "Labor Market Developments of Korea in Macroeconomic Perspectives." KDI Working Paper no. 8909. Korea Development Institute, Seoul.

Kim, Kyung-Keun. 1990. "Schooling and Married Women's Work in a Developing Country: The Case of the Republic of Korea." Ph.D. dissertation. University of Chicago, Department of Education.

Kong, Sae Kwon, and Minja Kim Choe. 1989. "Labor Force Participation of Married Women in Contemporary Korea." Journal of Population and Health Studies 9:116-36.

Koo, Bohn Young. 1985. "The Role of Direct Foreign Investment in Korea's Recent 
Economic Growth." In Foreign Trade and Investment: Economic Development in the Newly Industrializing Asian Countries, edited by Walter Galenson. Madison: University of Wisconsin Press.

Korea Association of Women Friends. 1989. The Reality of Women Clerical Workers and Their Movement. Seoul: Seok-Tap.

KPHI (Korea Population and Health Institute). 1987. Report of 1985 Fertility and Family Health Survey.

Krueger, Anne O. 1983. Trade and Employment in Developing Countries: Synthesis and Conclusions, vol. 3. Chicago: University of Chicago Press.

- 1991b. Social Indicators in Korea.

KSA (Korean Statistical Association). 1970, 1975, 1980, 1985, 1990, 1991a. Annual Report on the Economically Active Population Survey.

Kung, Lydia. 1983. Factory Women in Taiwan. Ann Arbor, Mich.: UMI Research Press.

KWDI (Korean Women's Development Institute). 1986. Socioeconomic Indicators of Women's Position.

Lee, Kwang-kyu. 1985. "Development of the Korean Kinship System with Special Reference to Influence from China." Bulletin of the Institute of Ethnology, Academia Sinica 59:163-89.

Lim, Linda Y. C. 1990. "Women's Work in Export Factories: The Politics of a Cause." Pp. 101-19 in Persistent Inequalities: Women and World Development, edited by Irene Tinker. New York: Oxford University Press.

Liu, Paul K. C. 1984. "Trends in Female Labor Force Participation in Taiwan." Pp. 75-100 in Women in the Urban and Industrial Workforce: Southeast and East Asia, edited by Gavin W. Jones. Honolulu: University of Hawaii Press.

London, Bruce. 1987. "Structural Determinants of Third World Urban Change." American Sociological Review 52:28-43.

Lundberg, Erik. 1979. "Fiscal and Monetary Policies." Pp. 263-307 in Economic Growth and Structural Change in Taiwan, edited by Walter Galenson. Ithaca, N.Y.: Cornell University Press.

Mason, Edward S., et al. 1980. The Economic and Social Modernization of the Republic of Korea. Cambridge, Mass.: Harvard University Press.

McGinn, Noel F., et al. 1980. Education and Development in Korea. Cambridge, Mass.: Harvard University Press.

Michell, Tony. 1988. From a Developing to a Newly Industrialized Country: The Republic of Korea, 1961-82. Geneva: International Labour Office.

Mincer, Jacob. 1962. "Labor Force Participation of Married Women: A Study of Labor Supply." In Aspects of Labor Economics, edited by H. Gregg Lewis. Princeton, N.J.: Princeton University Press.

Nash, June, and Maria Patricia Fernandez-Kelly, eds. 1983. Women, Men, and the International Division of Labor. Albany: State University of New York Press.

Oppenheimer, Valerie Kincade. 1970. The Female Labor Force in the United States. Westport, Conn.: Greenwood.

Papanek, Hanna. 1990. "To Each Less than She Needs, From Each More than She Can Do." Pp. 162-81 in Persistent Inequalities, edited by Irene Tinker. New York: Oxford University Press.

Park, M. H. 1991. "Patterns and Trends of Educational Mating in Korea." Korea Journal of Population and Development 20:1-16.

Pyle, Jean Larson. 1990. The State and Women in the Economy. Albany: State University of New York Press.

Ranis, Gustav. 1979. "Industrial Development." Pp. 206-62 in Economic Growth and Structural Change in Taiwan, edited by Walter Galenson. Ithaca, N.Y.: Cornell University Press.

Westview. 
Ranis, Gustav, and Chi Schive. 1985. "Direct Foreign Investment in Taiwan's Development." In Foreign Trade and Investment: Economic Development in the Newly Industrializing Asian Countries, edited by Walter Galenson. Madison: University of Wisconsin Press.

Reskin, Barbara F., and Patricia A. Roos. 1990: Job Queues, Gender Queues. Philadelphia: Temple University Press.

ROC (Republic of China). 1966. Statistical Abstract of the Republic of China. Prepared by the Directorate General of Budget, Accounting, and Statistics. Taipei.

- 1987. Yearbook of Manpower Statistics: Taiwan Area. Prepared by the Directorate General of Budget, Accounting, and Statistics. Taipei.

- 1990. Report on the Manpower Utilization Survey: Taiwan Area (see also 1989, 1991). Prepared by the Directorate General of Budget, Accounting, and Statistics. Taipei.

. 1969, 1981, 1991a. Monthly Bulletin of Manpower Statistics. Prepared by the Directorate General of Budget, Accounting, and Statistics. Taipei.

1991b. Social Indicators in Taiwan Area of the Republic of China. Prepared by the Directorate General of Budget, Accounting, and Statistics. Taipei.

. 1991c. Statistical Yearbook of the Republic of China. Prepared by the Directorate General of Budget, Accounting, and Statistics. Taipei.

ROK (Republic of Korea). 1970, 1975, 1980, 1985, 1990. Population and Housing Census Report. Prepared by the National Bureau of Statistics Economic Planning Board. Seoul.

- 1972, 1977, 1982, 1987, 1991. Statistical Yearbook of Education. Prepared by the Ministry of Education. Seoul.

- 1989. Report on the Employment Structure Survey. Prepared by the National Bureau of Statistics Economic Planning Board. Seoul.

Salaff, Janet. 1981. Working Daughters of Hong Kong. New York: Cambridge University Press.

Sassen, Saskia. 1988. The Mobility of Labor and Capital: A Study in International Investment and Capital Flow. Cambridge: Cambridge University Press.

Smock, Audrey C. 1981. Women's Education in Developing Countries. New York: Praeger.

Speare, Alden, Paul K. C. Liu, and Ching-lung Tsay. 1988. Urbanization and Development. Boulder, Colo.: Westview.

Standing, Guy. 1981. Labour Force Participation and Development, 2d ed. Geneva: International Labour Office.

Thurow, Lester. 1969. Poverty and Discrimination. Washington, D.C.: Brookings Institution.

Timberlake, Michael, ed. 1985. Urbanization in the World-Economy. Orlando, Fla.: Academic Press.

Tinker, Irene, ed. 1990. Persistent Inequalities. New York: Oxford University Press.

Tu, Jenn-hwa. 1990. Direct Foreign Investment and Economic Growth: A Case Study of Taiwan. Monograph Series no. 48. Taipei: Academia Sinica, Institute of Economics.

Ward, Kathryn, ed. 1990. Women Workers and Global Restructuring. Ithaca, N.Y.: ILR Press.

Wolf, Diane L. 1990. "Linking Women's Labor with the Global Economy." In Women Workers and Global Restructuring, edited by Kathryn Ward. Ithaca, N.Y.: ILR Press. 